\title{
Detection, Diversity, and Population Dynamics of Waterborne Phytophthora ramorum Populations
}

\author{
C. A. Eyre and M. Garbelotto
}

Forest Pathology and Mycology Laboratory, Department of Environmental Science, Policy and Management, University of California Berkeley, 54 Mulford Hall, Berkeley 94720.

Accepted for publication 2 July 2014.

\section{ABSTRACT}

Eyre, C. A., and Garbelotto, M. 2015. Detection, diversity, and population dynamics of waterborne Phytophthora ramorum populations. Phytopathology 105:57-68.

Sudden oak death, the tree disease caused by Phytophthora ramorum, has significant environmental and economic impacts on natural forests on the U.S. west coast, plantations in the United Kingdom, and in the worldwide nursery trade. Stream baiting is vital for monitoring and early detection of the pathogen in high-risk areas and is performed routinely; however, little is known about the nature of water-borne $P$. ramorum populations. Two drainages in an infested California forest were monitored intensively using stream-baiting for 2 years between 2009 and 2011. Pathogen presence was determined both by isolation and polymerase chain reaction (PCR) from symptomatic bait leaves. Isolates were analyzed using simple sequence repeats to study population dynamics and genetic structure through time. Isolation was successful primarily only during spring conditions, while PCR extended the period of pathogen detection to most of the year. Water populations were extremely diverse, and changed between seasons and years. A few abundant genotypes dominated the water during conditions considered optimal for aerial populations, and matched those dominant in aerial populations. Temporal patterns of genotypic diversification and evenness were identical among aerial, soil, and water populations, indicating that all three substrates are part of the same epidemiological cycle, strongly influenced by rainfall and sporulation on leaves. However, there was structuring between substrates, likely arising due to reduced selection pressure in the water. Additionally, water populations showed wholesale mixing of genotypes without the evident spatial autocorrelation present in leaf and soil populations

Additional keywords: drought, genetic diversity, multilocus genotypes.
Sudden oak death (SOD) is an emergent forest disease of particular significance on the west coast of North America, where it has severely affected huge swathes of native forest, causing an unprecedented mortality of oak and tanoak trees (23), with significant ecological consequences $(10,33,52)$. At the same time, the disease has caused large economic impacts in the nursery industry $(33,75)$, where the pathogen has been known to be present at least since 1993 (90), causing a disease currently named Ramorum blight (RB) (31). The forest disease was first described in the mid 1990s in the San Francisco Bay area (68) and has since been found in Oregon forests and Washington waterways, as well as in the waterways of a few other U.S. states $(29,54)$. The causal agent of both SOD and RB is an exotic generalist pathogen of unknown origin, called Phytophthora ramorum (90). Although $P$. ramorum is mostly found on ornamental plants and in nurseries in Europe $(8,87,90)$, it has recently reported to cause widespread mortality of planted Japanese larch in the United Kingdom and Ireland $(6,86)$.

Phytophthora spp. are fungus-like organisms in appearance and physiology but belong to the kingdom Stramenopila (5), and are generally well adapted to an aquatic environment (14). Their propagules can be found in rain, watercourses, soil water, soil, and even in the wind $(14,67)$. P. ramorum is an aerially adapted Phytophthora sp. producing deciduous rain-splashed sporangia on host leaves (12). Although sporangia can germinate and directly infect

Corresponding author: C. A. Eyre; E-mail address: ceyre@berkeley.edu

* The $e$-Xtra logo stands for "electronic extra" and indicates that the online version contains one supplemental table and one supplemental figure.

http://dx.doi.org/10.1094/PHYTO-07-13-0196-R

(c) 2015 The American Phytopathological Society a plant host, infection is more commonly caused by zoospores released from sporangia (23). Coast live oak (Quercus agrifolia), tanoak (Notholithocarpus densiflorus), and California bay laurel (Umbellularia californica) are major hosts in northern California forests but only leaves of the latter two species are known to support sporulation (23). Presence of rainfall and temperatures between 15 and $20^{\circ} \mathrm{C}$ are optimal for hyphal growth, sporulation, and infection $(3,12,18,38,81,90)$. Due to the Mediterranean climate encountered in most of its naturalized range in California, disease transmission occurs in the spring, when rainfall is present and temperatures are close to the $18^{\circ} \mathrm{C}$ optimum (38).

A vital part of the management of SOD hinges on monitoring and early detection of the pathogen in at-risk areas $(2,21,22$, $53,74)$. Early detection is extremely important to enable informed management decisions, resource allocation, and timely treatment or eradication interventions for this disease (21). Late-stage SOD symptoms on oak and tanoak include the sudden mortality of the entire canopy and can be identified by aerial and ground surveys in forests $(45,47)$. However, the pathogen also has significant yet hard to detect populations on bay laurel leaves, in the soil (18), and in natural waterways $(40,66,76,79)$. These populations are established before the mortality of infected oak and tanoak becomes apparent; hence, in order to achieve early pathogen detection, these substrates must be adequately monitored. As part of a U.S. national survey aimed at early detection of the pathogen, a program has been designed to identify the pathogen in drainages in which the pathogen is not known to be established but considered at risk either because it is at the edges of a current infestation or because a commercial nursery is located within it (83).

$P$. ramorum can be readily isolated from water but its abundance strongly fluctuates, following the cycles of aerial infes- 
tations $(9,34,42,48,66,76,79)$. Although the pathogen has been detected often at significant distances from known inoculum sources $(11,56)$, evidence in support of an epidemiological role of water populations is still lacking. Although many Phytophthora spp. are most frequently isolated from water, indicating that water is their preferred habitat (66), this is not the case for P. ramorum. Nonetheless, water infestations may potentially play a significant epidemiological role either by locally increasing disease incidence or by transporting the pathogen long distances. In Oregon, a strong association between SOD sites and their proximity to streams has been shown (60), and several other Oomycete pathogens are known to disperse via natural watercourses, including P. lateralis (32), P. siskiyouensis (65), and P. cinnamomi (46). Many Phytophthora spp., including $P$. ramorum, are also frequently detected in nursery irrigation water, especially when water is recycled $(25,37,39,43)$, and this contaminated water has the potential to spread the disease both within and adjacent to nurseries $(71,91)$. Thus, it is especially important to monitor areas outside of the current infection range and near nurseries to catch any enlargement of the known infestation area (80), to determine inoculum loads $(9,39,42,66)$, and to gauge the success of eradication efforts $(19,44,84)$.

Several methods are used for monitoring and detection of $P$. ramorum in the water; they usually include catching the inoculum by filtration (40) or by baiting $(12,56,57,65,66,79)$, followed by either direct culturing, polymerase chain reaction (PCR) $(58,70)$, or enzyme-linked immunosorbent assay (78) for diagnosis. Each method has it merits, and several studies have compared the efficacy of the various approaches $(1,37,58,76,78)$. Nonetheless, stream baiting is the mainstay of water monitoring and has been used extensively to detect and monitor the presence of $P$. ramorum and of other Phytophthora spp. in both forests and nurseries $(9,40,42,48,56,66,76,79,80,82)$. Baiting is commonly carried out together with PCR assays (76), and the general consensus is that a combination of methods gives the most robust monitoring scheme $(58,76)$. Indeed, surveys designed this way have detected the pathogen in the water where above-ground infestations were originally unknown but were later discovered during follow-up ground surveys $(9,42,76)$.

Although monitoring for the presence of $P$. ramorum in the water has been extensive, there has been virtually no study of the genetic diversity or structure of water-borne $P$. ramorum populations. Several studies have determined the genetic structure of $P$. ramorum populations in leaves and soil $(11,17,27,50,51,61,62,87)$ to infer the history and migration of the disease but none have focused on the population resident in the water. In this study, isolates yielded from the systematic surveys of two drainages were analyzed using simple sequence repeat or microsatellite markers to study the genetic diversity and the spatiotemporal genetic structure of water populations, and to investigate whether there is any specialization, adaptation, or selection of individuals to an aquatic habit. This was made possible by a concurrent analysis of leaf and soil populations performed in the same area and previously published (17). The implications of seasonal and geographical variation in diversity and structure of water populations in relation to soil and leaf populations are discussed with regards to pathogen dispersal and biology, as well as disease management.

Specific aims of the study were to (i) identify the optimal method and time frame to detect and quantify $P$. ramorum in the water with changing environmental conditions; (ii) assess genetic diversity and population structure dynamics of waterborne $P$. ramorum populations in relation to season and drainage; (iii) describe genotypic diversity and the genetic and spatial structures of water populations at different sampling times, including comparisons between drainages and between upper and lower sections within drainage; and (iv) investigate whether there is evidence for selection for particular genotypes in the water, and compare the epidemiology of aquatic $P$. ramorum populations with those of soil and leaves.

\section{MATERIALS AND METHODS}

Baiting site selection. Our sampling was carried out within the San Francisco Public Utilities Commission (SFPUC) watershed district in San Mateo County (latitude: 37.525, longitude: $-122.365)$. The area comprises 9,300 ha closed to the public and relatively undisturbed. The area is dominated by mixed stands of California bay laurel, Coast live oak, and tanoak, and has been infested with SOD since 2001 (11). Sampling was conducted in sites within two drainages, Pilarcitos and Crystal Springs, which range in elevation from 95 to $320 \mathrm{~m}$ (Supplemental Figure 1). Pilarcitos is, on average, higher than Crystal Springs and, although monthly rainfall is similar in both drainages, it is consistently slightly higher in Pilarcitos. Pilarcitos is also the only drainage to include tanoak.

Stream baiting sites were selected based on their accessibility and proximity to infected forests along two drainages within the watershed. Seven sites were located within the Pilarcitos drainage and another seven within the Crystal Springs drainage. Two sites along the Pilarcitos drainage were located outside of the SFPUC watershed in the Coastside San Mateo County Water District land but in a comparable type of habitat. Sites were placed at least 1 $\mathrm{km}$ apart along waterways and in areas with running water, theoretically not subject to large fluctuations in water level and shade.

The rainfall data we used was collected by the SFPUC in six gauges located around the watershed. Overall, rainfall was calculated as mean rainfall accumulation based on daily recordings in the calendar month, or in the 7,14 or 30 days preceding each collections of baits. Rainfall for individual drainages was calculated as above but using only local gauges. Rainfall data were used in correlation calculations and regression-model-fitting analyses together with water temperature and detection success for each sampling time. Air temperature data were acquired from a remote automated weather station (RAWS) (USA Climate Archive: www.raws.dri.edu) at Pulgas, located within the SFPUC (latitude: 37.475, longitude: -122.298). A monthly aridity index $\left(\mathrm{AI}_{\mathrm{m}}\right)$ was calculated as $\mathrm{AI}_{\mathrm{m}}=12 \mathrm{P} /(\mathrm{T}+10)$, where $\mathrm{P}$ is the monthly precipitation (in millimeters) and $\mathrm{T}$ is the mean air temperature $\left({ }^{\circ} \mathrm{C}\right)(13)$; note that index values are low when aridity is high.

Stream baiting. Sampling took place over a 2-year period starting in April 2009 and ending in April 2011. Baitings were performed at 2- to 3-week intervals during the spring and summer and at monthly intervals during the fall and winter, except for when access to each site was not possible. At each baiting site, 10 uninfected Rhododendron var. Cunningham's White leaves were placed within mesh bags, tethered to the riverbank, and floated in the stream. Collected leaves were refrigerated for a maximum of $48 \mathrm{~h}$ before plating. Water temperature was measured at each site at the time of leaf collection and the average taken across groups and time scales being compared.

At two time points, in 2010 (April and May) during "Peak" season, 100 leaves were deployed at one site in the Pilarcitos drainage in addition to the usual 10. The use of 100 leaves allowed for (i) a comparison with results obtained with the 10 leaves and (ii) a better calculation of genotypic frequency at one location during one time period. In particular, we were interested in determining whether, during spells climatically favorable to aerial $P$. ramorum populations, we could observe dominance of one or few genotypes in the water, as previously observed for leaf populations (17). In all sampling times but the two cited above, only data from 10 leaves were employed.

Culture isolation. Small leaf sections were excised aseptically from the edges of lesions of each of the collected Rhododendron 
leaves and buried under the surface of PARP amended with hymexazol (PARP+H) selective medium (pimaricin at $400 \mu \mathrm{l} / \mathrm{liter}$, ampicillin at $250 \mathrm{mg} / \mathrm{liter}$, rifampicin at $10 \mathrm{mg} / \mathrm{liter}$, pentachloronitrobenzene at $25 \mathrm{mg} / \mathrm{liter}$, and hymexazol at $25 \mathrm{mg} / \mathrm{liter}$ ) (88). Plates were incubated in the dark at $18^{\circ} \mathrm{C}$ for up to a week and inspected daily for mycelial growth. Growth usually occurred after 2 to 3 days. $P$. ramorum growth was identified morphologically, based on hyphal and chlamydospore structure, and up to 10 isolates (i.e., one viable culture per leaf) were subcultured from a single baiting station for genotyping. Other species of Phytophthora were observed in culture from leaf sections but species other than $P$. ramorum were not identified and stored.

DNA extraction from mycelium. Mycelial isolates, maintained on PARP (88), were inoculated into $12 \%$ pea broth (peas at $120 \mathrm{~g} / \mathrm{liter}$ ) liquid culture and grown for 1 week at room temperature, followed by lyophilization. Lyophilized mycelium was ground using 5-mm glass beads and a bead amalgamator. DNA was extracted by addition of $200 \mu \mathrm{l}$ of $0.5 \mathrm{M} \mathrm{NaOH}$ to $\approx 10 \mathrm{ng}$ of crushed mycelium, mixed thoroughly, followed by dilution of $5 \mu \mathrm{l}$ of this in $495 \mu \mathrm{l}$ of $10 \mathrm{mM}$ Tris-HCl, $\mathrm{pH} 8.0$ (59).

PCR detection of $P$. ramorum from bait leaves. A single hole punch was taken from each of the 10 leaves collected from each site. Punches were taken from the edges of lesions, with three to four discs placed in 2-ml tubes together for extraction, yielding up to three replicates per sample. Occasionally, leaves were washed away in streams, reducing the sample size. Leaf discs were frozen at $-20^{\circ} \mathrm{C}$ and lyophilized for $48 \mathrm{~h}$ before grinding to powder with a glass bead in an amalgamator. DNA was extracted from the resulting leaf powder using a cetyl trimethyl ammonium bromide/phenol:chloroform:isoamyl alcohol and Geneclean kit (Qbiogene Inc.) (36). Leaf DNA extracts were tested for the presence of the pathogen using a $P$. ramorum-specific TaqMan real-time PCR diagnostic assay (36). A PCR-positive result was recorded if $P$. ramorum was detected in at least one of three replicates. Leaf punches of uninfected lettuce leaves were DNA extracted and tested alongside samples as controls.

Microsatellite genotyping. $P$. ramorum DNA was amplified using a set of six primers, specific to $P$. ramorum, amplifying a total of 10 microsatellite loci: Ms18 and 64 (41); Ms39, 43, and 45 (62); and MsILVO145 (87). PCRs (10 $\mu$ l each) were set up with final concentration for each reaction as follows: $5 \times$ PCR buffer, $1.5 \mathrm{mM} \mathrm{MgCl}_{2}, 200 \mu \mathrm{M}$ dNTPs, $0.2 \mu \mathrm{M}$ F primer (labeled with HEX or FAM), $0.2 \mu \mathrm{M}$ R primer, and GoFlexiTaq (Promega) at $1 \mathrm{U} / \mu \mathrm{l}$. Thermal cycling programs varied for different primers sets and were taken from the literature $(41,62,87)$. Fragment analyses of PCR products were run with a LIZ 500 size standard on a 3730 ABI Sequencer (Applied Biosystems). Peakscanner v1 (ABI Biosystems) was used for fragment analysis. Multilocus genotypes (MLGs) were assigned using Gimlet v1.1.3 (85) (Supplemental Table 1). For comparative analyses of genotypes among substrates (soil, leaves, and water), soil and leaf MLGs were those defined by Eyre et al. (17) and are reported in tables summarizing the comparative results.

Genetic diversity indices. The following indices were calculated: (i) Stoddart and Taylor's index of genotypic diversity, $G=1 / \Sigma p_{\mathrm{i}}^{2}$ (73), where $p_{\mathrm{i}}$ is the frequency of the $i$ th MLG; and (ii) MLG evenness, using the index E5 (30): E5 $=(1 / \lambda)-1 / \mathrm{e}^{\mathrm{H}^{\prime}}-1$, where $\lambda=$ Simpson's index of diversity and $\mathrm{H}^{\prime}=$ the ShannonWiener diversity index. If E5 $=1$, then all genotypes are equally represented; whereas, as E5 approaches 0, dominance of a few genotypes or a single genotype becomes prevalent. Indices were calculated for each calendar month and drainage, each divided into upper and lower portions. Allelic richness versus sample size curves were constructed by rarefaction using ADZE v1.0 (77).

Analyses of genetic structure. Populations were tested for genetic structure using analysis of molecular variance (AMOVA) as implemented by Arlequin v3.5.1.2 (15). AMOVA was performed with 10,000 permutations and using an external matrix of
Bruvo distances (7), calculated using Genodive 2.0b10 (55). AMOVAs were used to test for genetic structuring (i) between years for each drainage separately; (ii) between drainages; and (iii) between water, soil, and leaf populations. Analyses were also performed with a dataset where all singletons were removed, leaving only those MLGs which were present more than once. $P$. ramorum reproduces asexually; therefore, alleles are essentially linked as a result. However, high mutational rates at the different loci creates some independence in allele state among loci. A pairwise comparison of allelic variation also showed that no two loci had alleles that were cosegregating. All polymorphic loci were included in the analysis. Invariant loci were ignored in the analysis methods we used.

Spatial autocorrelation analyses were used to determine the presence of allelic aggregation at varying distances, using Spagedi v1.3 (35). Analyses were performed separately by drainage. Spatial coordinates for each baiting site were supplied in UTM format (WGS84). Moran's index of genetic similarity I (72) was plotted against distance. In total, 20,000 permutations were used for significance testing of Moran's I.

A minimum spanning network was constructed using all MLGs from both 2009 and 2010 to visualize the relationship between MLGs in the water population. Bruvo distances (7) and MINSPNET (16) were used to construct a network that was visualized using Graphviz v2.28 (www.graphviz.org).

Statistical analyses. Culture positives and PCR positive and negative data results were coded as binary presence or absence scores. Force of infection (FOI) was calculated as the percentage of positive isolations from the previous sampling time. Linear regression was used to test the relationship between air temperature and rainfall. After significant correlation was found between them (see Results), the aridity index (AI) was used to combine both variables in further analyses. (17). Generalized linear models, using the binomial distribution and logit link function and maximum likelihood estimation, were employed to determine the relationship between the independent variables FOI, AI, and the response variable culture positives. Models were run with each variable independently, then combined in a multivariate approach. The Akaike Information Criterion with small sample size correction (AICc) was used as a criterion for model selection. Spearman's rank tests were used to compare the ranks of the most abundant genotypes compared between soil, leaf, and water populations. JMP v10.0 (SAS Institute Inc., Cary, NC, 1989 to 2013) was used for all analyses.

\section{RESULTS}

$\boldsymbol{P}$. ramorum recovery. During the sampling period, 2,740 leaf baits were deployed at 29 sampling times in 14 sites. Occasionally, bait leaves would be washed away, sites would become temporarily inaccessible, or water levels made baiting impossible, resulting in unavailable or reduced collections. In total, 554 isolations of $P$. ramorum were obtained. Other Phytophthora spp. often grew out of plated leaf bait sections but these were not identified or stored. Excluding the 100 leaf-bait experiment (see Materials and Methods), 378 isolates were obtained in this study. As a general trend, isolations were mostly successful between March and July of each year (Table 1; Fig. 1). Isolation success (Cult+) across all sites ranged from $3(2.5 \%)$ isolates in July 2010 to 51 (36 to 39\%) isolates in both April and May 2010 (Table 1; Fig. 1). In general, isolation attempts were unsuccessful between August and February (although sampling was not always possible due to access issues), with the exception of December 2010, in which $12(8.5 \%)$ isolations were made. Maximum isolate recovery occurred each year during the spring months, including the following results: May $2009(n=42)$, April $2010(n=51)$, and April $2011(n=38)$ (Table 1; Fig. 1). Isolation success averaged across all baiting stations and sampling times was greater in the 
Pilarcitos than in the Crystal Springs drainage (20 versus 6\% success; Wilcoxon test, $P=0.02$ ).

$P$. ramorum diagnostic PCR assay. $P$. ramorum was detected in leaves throughout the year using the PCR diagnostic (PCR+) assay. Generally, when a $P$. ramorum culture was isolated (Cult+) (i.e., between March and July of each year), the PCR diagnostic was also positive (Cult+/PCR+), with occasional exceptions due to random PCR failures (Fig. 2). In the summer and winter months (August to February), P. ramorum was detected by PCR in many sites where isolations failed (Cult-/PCR+). The majority of the Pilarcitos sites were PCR+ throughout the study but Crystal Springs sites were less consistent. Sites with negative results in both assays (Cult-/PCR-) tended to occur between July and December, with increasing frequency as time since the last rain event increased (Fig. 2).

Rainfall and water temperature. Rainfall in the watershed was strongly seasonal. Peak average rainfall was recorded in the winter months of each year (2009: February $=9.64 \mathrm{~cm} ; 2010$ : January $=7.69 \mathrm{~cm}$ and December $=8.87 \mathrm{~cm} ; 2011$ : March $=$ $8.37 \mathrm{~cm}$ ). The winter-to-spring transition between 2010 and 2011 was characterized by two rainfall peaks, one in December (uncharacteristic for the 2000-2010 decade) and one in March. Rainfall decreased during the late spring (March to May) and became nil during the summer to early fall (June to September) (Table 1). The Pilarcitos drainage was wetter on average than the Crystal Springs drainage throughout the sampling period. Average water temperature across sites (Table 1) followed an inverse seasonal cycle to that of rainfall. Water temperatures were between 9.2 and $18.8^{\circ} \mathrm{C}$, with the highest temperatures recorded during the summer to early fall (July, August, September, and October) and lowest in late fall to winter (November and December). Water temperature was most significantly negatively correlated with rainfall when the preceding 31 days of rainfall were considered $(r=-0.51, P<0.0001)$.

Overall, aridity was greater in $2009\left(\mathrm{AI}_{\mathrm{m}}=17.90\right)$ than in 2010 $\left(\mathrm{AI}_{\mathrm{m}}=32.21\right)($ Fig. 1$)$. The most arid conditions $\left(\mathrm{AI}_{\mathrm{m}}=0\right)$ were recorded in July 2009 and July, August, and September 2010. The lowest aridity (highest index value) was generally recorded during the spring or in late winter: March $2009=60.17$, February $2010=$ 124.04, and April $2011=117.24$. Temperature and rainfall had a significant linear fit $\left(R^{2}=0.39, F=202.9, P<0.0001\right)$ and, therefore, are not independent variables: rainfall $=225.28449-$ $12.143607 \times$ temperature. Whole-model tests based on general linear model (GLM) and using FOI and AI separately to explain percentage of positive cultures were both significant $(P<0.0001$ and 0.0001 , respectively), and returned AICc values of 1568.92 and 1598.01, respectively. When both variables were included in the model, their effects were still significant $(P<0.0001)$ but AICc decreased $(\mathrm{AICc}=1177.03)$, indicating that the combined model was a better fit for the data and that, together, both variables better explain culture positives at each sampling time.

Multilocus genotyping. In total, 91 different MLGs were detected from 363 of the 378 isolates collected. For 15 isolates, only partial MLGs could be assigned; therefore, they were excluded from further analyses. Fifty-one of the MLGs $(13.5 \%$ of total individuals) were singletons (i.e., represented by one individual). The most abundant genotype, MLG 43, was found 75 times (19.8\% of total isolates), while the second most abundant, MLG 66, was found 30 times (7.9\%). MLG 48 and MLG 102 tied as third most abundant genotypes $(n=20,5.3 \%)$ (Table 2$)$. The proportion of MLGs detected in multiple years was relatively low: $20 \%$ of MLGs were detected in 2 years and only $13.5 \%$ MLGs were present in all 3 years.

Bait leaves: 100 versus 10. A similar pattern of results was found in both replicates of this trial (April and May 2010) (correlation of MLG frequencies: $R^{2}=0.962, P<0.05$ ). In April, 100 leaves yielded 83 isolations, representing 40 different MLGs. In May, 100 leaves yielded 91 isolates, representing 36 MLGs. MLG 43 was most common in both trials (April: $n=14,20 \%$; May: $n=22,24 \%$ ). The second most abundant MLGs were less well represented, with MLG 66 accounting for $8 \%(n=7)$ in April and MLG 9 accounting for $7 \%$ in May $(n=6)$. The remaining MLGs in both samples had $\leq 5$ representatives, a large proportion of which were singletons (April: $n=23,28 \%$; May:

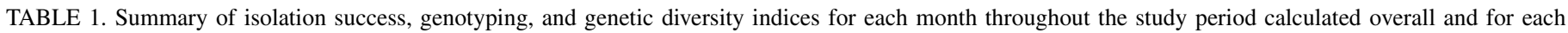
drainage separately ${ }^{\mathrm{a}}$

\begin{tabular}{|c|c|c|c|c|c|c|c|c|c|}
\hline Year, month & Leaves & $N$ & MLGs & Diversity $(G)$ & Evenness (E5) & Rainfall (mm) & Air $\left({ }^{\circ} \mathrm{C}\right)$ & Aridity & Water $\left({ }^{\circ} \mathrm{C}\right)$ \\
\hline \multicolumn{10}{|l|}{2009} \\
\hline March & 120 & 6 & 5 & 4.5 & 0.93 & 105 & 11 & 60 & 12 \\
\hline April & 120 & 26 & 12 & 6.5 & 0.71 & 26 & 11 & 15 & 12 \\
\hline May & 120 & 42 & 19 & 11.92 & 0.79 & 13.2 & 13.7 & 6.67 & 16 \\
\hline June & 100 & 6 & 6 & 6 & 1 & 0.5 & 15 & 0.2 & $\ldots$ \\
\hline July & 100 & 23 & 12 & 7.9 & 0.81 & 0 & 18 & 0 & 18 \\
\hline August & 130 & $\ldots$ & $\ldots$ & $\ldots$ & $\ldots$ & 1.5 & 19 & 0.6 & 19 \\
\hline September & 130 & $\ldots$ & $\ldots$ & $\ldots$ & $\ldots$ & 5.6 & 20 & 2.2 & 19 \\
\hline October & 110 & $\ldots$ & $\ldots$ & $\ldots$ & $\ldots$ & 120 & 16 & 55 & $\ldots$ \\
\hline November & 140 & $\ldots$ & $\ldots$ & $\ldots$ & $\ldots$ & 0.8 & 14 & 0.4 & 10 \\
\hline December & 140 & 12 & 8 & 4.5 & 0.68 & 65 & 9.9 & 39 & 11 \\
\hline \multicolumn{10}{|l|}{2010} \\
\hline March & 140 & 45 & 24 & 13.06 & 0.7 & 79.8 & 11.6 & 44.4 & 11 \\
\hline April & 140 & 51 & 18 & 9.74 & 0.74 & 120 & 12 & 66 & 11.5 \\
\hline May & 130 & 51 & 20 & 8.05 & 0.63 & 118 & 12 & 64 & 14 \\
\hline June & 110 & 35 & 20 & 6.92 & 0.51 & 21 & 13 & 11 & 15 \\
\hline July & 120 & 3 & 3 & 3 & 1 & 0 & 17 & 0 & 18 \\
\hline August & 120 & $\ldots$ & $\ldots$ & $\ldots$ & $\ldots$ & 0 & 17 & 0 & 18 \\
\hline September & 110 & $\ldots$ & $\ldots$ & $\ldots$ & $\ldots$ & 0 & 18 & 0 & 18 \\
\hline October & 120 & $\ldots$ & $\ldots$ & $\ldots$ & $\ldots$ & 1.8 & 19 & 0.7 & 15 \\
\hline November & 120 & $\ldots$ & $\ldots$ & $\ldots$ & $\ldots$ & 25 & 15 & 12 & 10.5 \\
\hline \multicolumn{10}{|l|}{2011} \\
\hline April & 130 & 31 & 16 & 10.12 & 0.79 & 208 & 11 & 117 & 13 \\
\hline May & 130 & 29 & 23 & 17.89 & 0.86 & 5.6 & 12 & 3 & 14 \\
\hline June & 130 & 6 & 5 & 4.5 & 0.93 & 43 & 13 & 23 & 18 \\
\hline
\end{tabular}

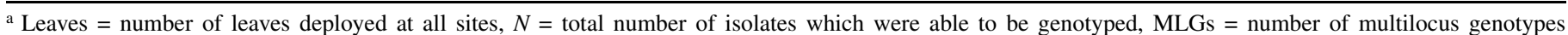
detected, Diversity = Stoddart and Taylor's diversity index, Evenness = evenness index (data from the 100 leaf deployments is excluded), Rainfall = total cumulative rainfall in the 30 days preceding sample collection, Air = mean air temperature for 30 days preceding sample collection, Aridity = index combining rainfall and temperature, and Water $=$ mean water temperature across all sites when leaves retrieved. 
$n=19,21 \%$ ). The 10 bait leaves yielded seven MLGs from nine isolations in April and seven MLGs from seven isolations in May (i.e., all singletons). Both 10-leaf samples included MLG 43, the most common in the 100-leaf samples. In April, the 10-leaf sample MLGs were all also found in the 100 leaves sampled at the same time. In May, only five of the seven MLGs found in the 10-leaf sample were also present in the 100-leaf sample; the remaining two MLGs were unique to this sample.

Genetic diversity and structure. Temporal. Pilarcitos and Crystal Springs followed the same overall pattern of diversity. Values for Stoddart and Taylor's $G$ were always greatest in April or May (Peaks: May $2009=11.9$, March $2010=13.06$, and April $2011=17.89$ ) and decreased during other times (Table 1; Fig. 1). E5 peaked in June 2009 (1.00) and July 2010 (1.00), and was lowest in April 2009 (0.71) and June 2010 (0.51) (Table 1; Fig. 1).

Spatial. Diversity was compared between upper and lower drainages for each year. $G$, which is not scaled for sample size, was initially greater in the upper drainage in 2009 for both Pilarcitos and Crystal Springs (Fig. 3). In Pilarcitos, $G$ for the upper drainage was reduced slightly but remained relatively stable across years (2009 to 2011), whereas diversity in the lower drainage increased with time. In Crystal Springs, instead, diversity in the upper drainage decreased while diversity in the lower drainage increased (Fig. 3). In 2011, there were insufficient individuals to calculate indices for the upper and lower Crystal Springs drainage separately. Isolation success, a metric that can be used as a measure of inoculum load, increased in the lower drainages, following a pattern that mirrors the changes of $G$ described above (Fig. 3). E5 was consistently higher in the lower Pilarcitos drainage when compared with the upper drainage. The difference between upper and lower drainage was greatest in 2009 and reduced in 2010 and 2011 (Fig. 3). The lowest E5 values were recorded in 2010 for both the upper and lower Pilarcitos drainages. Crystal Springs had less consistent results. Although, in 2009, the results were consistent with those in the Pilarcitos drainage (i.e., lower drainage had higher E5 than upper), this pattern was reversed in 2010. It should be noted, however, that values were rather similar between years (E5 in 2009: upper = 0.787 , lower $=0.931$; in 2010: upper $=0.8681$, lower $=0.775$ ).

Allelic richness curves were constructed for all sampling times and populations used in AMOVA analyses (i.e., individual drainages in each year and for upper and lower drainage populations) (Fig. 4). All groups had a sufficient sample size for a plateau to be reached and, therefore, provide a good representation of the genetic diversity present. The exception was July $2010(n=3)$, which was excluded from all analyses where sampling months were treated separately but was included in analyses when months were grouped for seasonal analysis. Similarly, the Crystal Springs populations in 2011 were insufficient to reach a plateau and, therefore, were excluded from analyses.

Drainages were compared within each year separately using AMOVA. There was slight yet significant structuring between drainages in 2009 (fixation index $[\mathrm{FST}]=0.0638, P=0.00079$ ) and 2010 (FST $=0.05603, P=0.0000$ ) but no structure evident between drainages in 2011. When populations from the same drainage were compared among years (Pilarcitos: 2009 versus 2010 versus 2011; Crystal Springs: 2009 versus 2010), there was significant structure between years in Pilarcitos $(\mathrm{FST}=0.03663$, $P=0.0000$ ) but not in Crystal Springs (FST $=0.01656, P=$ 0.1178 ). The same results were obtained when analyses were run using an edited dataset with singletons removed.

MLGs compared among substrates (water, soil, and leaf). AMOVA analyses found significant structure among populations in each substrate (water, soil, and leaves) within each year. The difference among substrates was greater in 2009 (FST $=0.05114$, $P=0.000)$ than in $2010(\mathrm{FST}=0.03288, P=0.000)$. Pairwise comparisons between substrates showed that, in 2009, leaf and soil populations were more different from water populations than
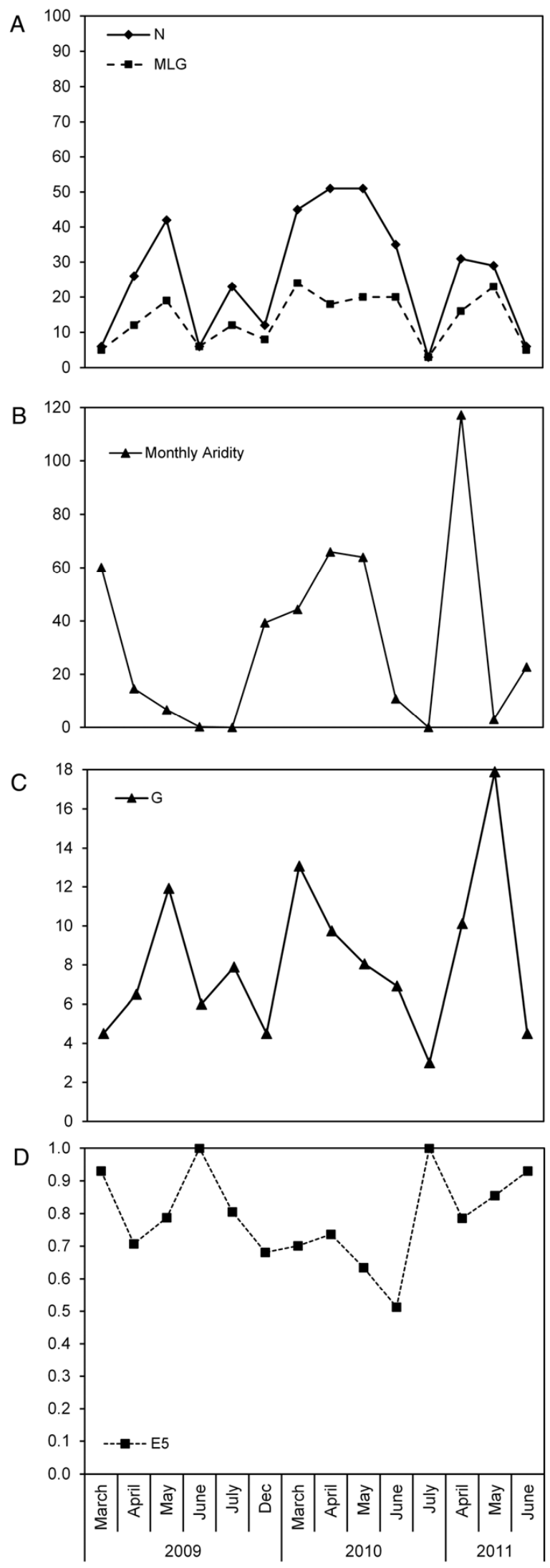

Fig. 1. Isolation success, aridity index, simple sequence repeat genotyping, and diversity and evenness indices for each sampling month in which isolations were made throughout study. A, Number of isolates collected $(N)$ and multilocus genotypes (MLGs) assigned, B, monthly aridity index calculated with a combination of rainfall and air temperature data, $\mathbf{C}$, Stoddart and Taylor's index of genotypic diversity (G), and D, evenness index (E5). 
they were from each other (2009: leaf versus soil FST $=0.0045$, $P=0.1837$; soil versus water FST $=0.07048, P=0.000$; water versus leaf FST $=0.07657, P=0.000)$. In 2010, the greatest difference was between soil and water populations $(\mathrm{FST}=$ $0.05083, P=0.000)$. There was less structure between leaf and soil $(\mathrm{FST}=0.03321, P=0.0003)$ and leaf and water $(\mathrm{FST}=$ $0.02823, P=0.000)$.

The 10 most abundant MLGs found in stream baiting samples were compared with those found in soil and leaf samples collected in the same drainages within the SFPUC watershed (17). Stream bait samples from 2011 and their associated genotypes were removed from the comparisons because soil and leaf samples were collected only in 2009 and 2010. MLG 43 was the most abundant genotype in all three substrates (water: $n=65 / 299$, leaf: $n=62 / 387$, soil: $n=22 / 130$ ) (Table 2). Several MLGs were shared in the top 10 for each substrate. However, some MLGs were highly abundant in one substrate but completely absent from the top 10 of others. MLG 101 and MLG 9 were found 14 and 13 times, respectively, in water samples but did not feature in the top 10 of either leaf or soil samples. Two Spearman's rank analyses were performed: (i) genotypes present in both water and soil $(\rho=$ $0.6232, n=15, P=0.0192$ ) and (ii) genotypes present in both water and leaves $(\rho=0.4898, n=24, P=0.0188)$. There were significant correlations between the ranks of shared genotypes, with a stronger correlation between water and soil.

Singleton MLGs were more prevalent in water samples than in soil and leaves in both 2009 and 2010. The proportion of singletons in the water population was more or less stable between 2009
(61\% singleton MLGs representing 20\% of individuals) and 2010 (62\% singleton MLGs, $19 \%$ of individuals) but increased in 2011 (74\% singleton MLGs, $42 \%$ of individuals). Similar increases were also seen in soil and leaf populations: the soil population in 2009 had $35 \%$ singleton MLGs (10\% of individuals), which increased to $48 \%$ singleton MLGs (19\% of individuals) in 2010, while the leaf population in 2009 had $45 \%$ singleton MLGs (9\% of individuals), increasing to $56 \%$ singleton MLGs (14\% of individuals) in 2010.

A large proportion of the MLGs were only ever detected in water samples: the majority of these "water-only" MLGs were singletons. In 2009 stream baiting, 64\% of the MLGs detected were water-only (25 of 39), representing $47 \%(n=55)$ of all the isolates collected that year. Of these water-only MLGs, 19 (76\%) were singletons. In 2010, 53\% of MLGs detected were water-only ( 31 of 58$)$, representing $24 \%(n=46)$ of all isolates collected. In all, $74 \%$ of the water only MLGs were singletons $(n=23)$. (Table 3 ). However, the number of water-only MLGs that were carried over between years was small: just $13 \%$ (13\% of individuals) were carried over from 2009 to 2010 and $17 \%$ of MLGs (14\% of individuals) from 2010 to 2011.

Minimum spanning network. The minimum spanning network showed that the diverse water population is highly interconnected with the soil and leaf populations (Fig. 5). Blue nodes within the minimum spanning network are those genotypes that were only found in water populations when compared with soil and leaf populations sampled from the same area in the same years, based also on Eyre et al. (17). The majority of the water-

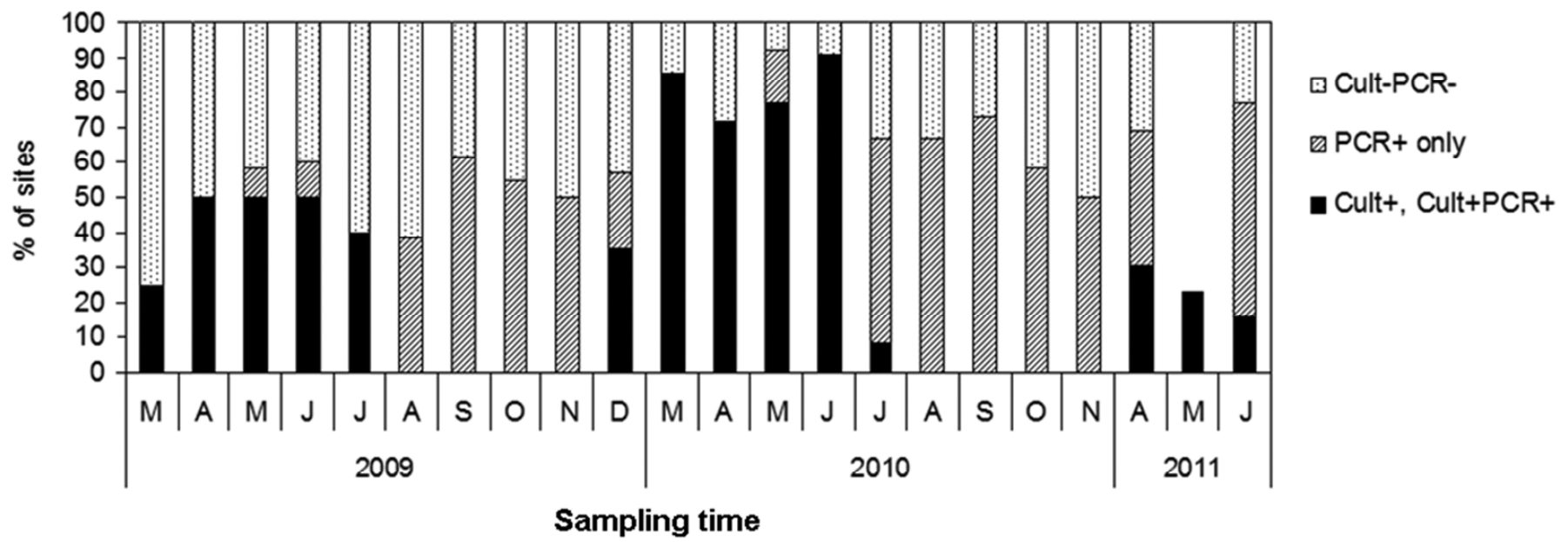

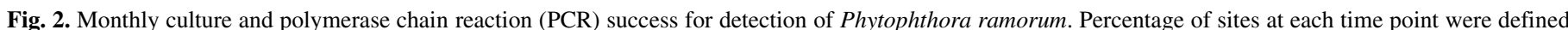

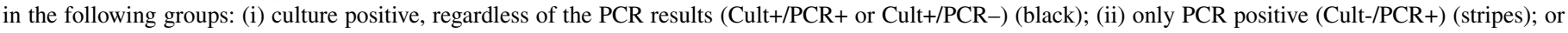
(iii) negative in both assays (Cult-/PCR-) (dots). May $2011=$ culturing only.

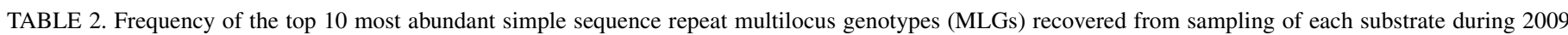
and 2010 in the San Francisco Public Utilities Commission watershed area $^{\mathrm{a}}$

\begin{tabular}{|c|c|c|c|c|c|c|c|c|c|}
\hline \multirow[b]{2}{*}{ Rank } & \multicolumn{3}{|c|}{ Water } & \multicolumn{3}{|c|}{ Leaf } & \multicolumn{3}{|c|}{ Soil } \\
\hline & MLG & $N$ & $\%$ & MLG & $N$ & $\%$ & MLG & $N$ & $\%$ \\
\hline 1 & 43 & 65 & 18 & 43 & 62 & 16 & 43 & 22 & 17 \\
\hline 2 & 66 & 22 & 6 & 52 & 61 & 16 & 57 & 14 & 11 \\
\hline 3 & 48 & 18 & 5 & 66 & 30 & 8 & 66 & 12 & 9 \\
\hline 4 & 102 & 17 & 5 & 102 & 28 & 7 & 36 & 10 & 8 \\
\hline 5 & 57 & 14 & 4 & 57 & 26 & 7 & 52 & 9 & 7 \\
\hline 6 & 101 & 14 & 4 & 36 & 16 & 4 & 59 & 9 & 7 \\
\hline 7 & 9 & 13 & 4 & 59 & 16 & 4 & 102 & 6 & 5 \\
\hline 8 & 36 & 10 & 3 & 118 & 16 & 4 & 132 & 5 & 4 \\
\hline 9 & 2 & 9 & 2 & 48 & 13 & 3 & 48 & 4 & 3 \\
\hline 10 & 84 & 8 & 2 & 106 & 10 & 3 & 72 & 4 & 3 \\
\hline Total & $\ldots$ & 363 & 52 & $\ldots$ & 388 & 72 & $\ldots$ & 131 & 73 \\
\hline
\end{tabular}

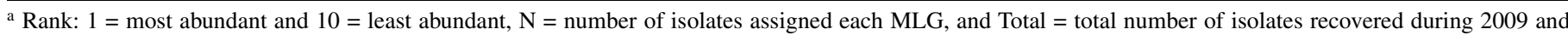
2010. 
only genotypes were singletons evenly spread around the network generally concentrated at the periphery and connected to the central multiple cross-linked network by a single connection. There was one chain of six MLGs that were water-only and all closely related in an offshoot in the lower part of the network (Fig. 5).
Spatial autocorrelation. Spatial autocorrelation analyses were performed on data for each drainage and year separately. In both drainages and across all 3 years, the genetic similarity index, Moran's $I$, was consistently within the upper and lower significance thresholds, at almost all distances (in meters), indicating no aggregation of alleles (data not shown).
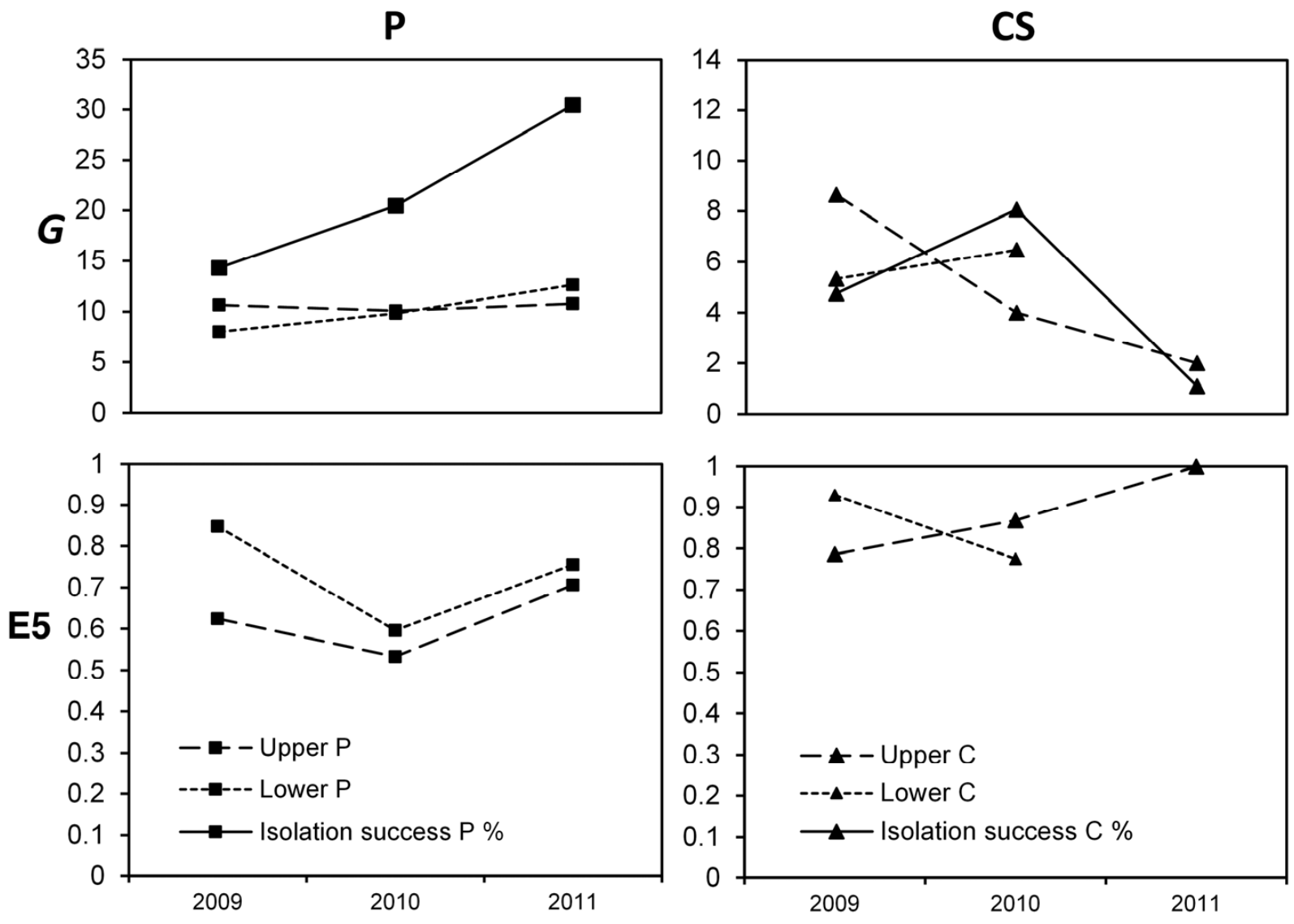

Fig. 3. Isolation success, Stoddart and Taylor's diversity $(\mathrm{G})$ and Evenness (E5) indices for each drainage divided into upper and lower sections. $\mathrm{P}=\mathrm{Pilarcitos}$ drainage and $\mathrm{C}=$ Crystal Springs drainage.

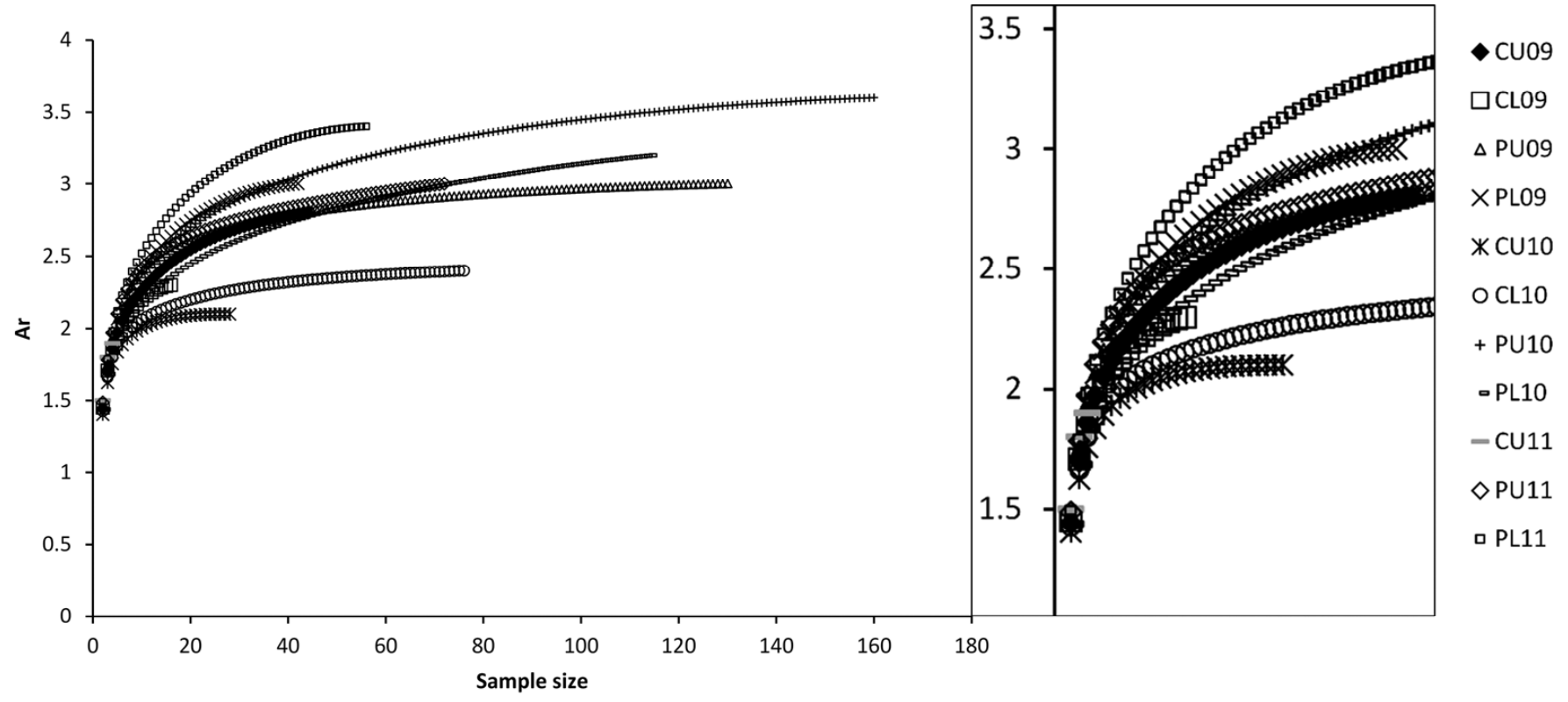

Fig. 4. Allelic richness curves for populations in upper and lower drainage that were used in analysis of molecular variance analyses testing for genetic structuring between populations. $\mathrm{P}=$ Pilarcitos drainage, $\mathrm{C}=$ Crystal Springs drainage, $\mathrm{U}=$ upper drainage, $\mathrm{L}=$ lower drainage, $09=2009,10=2010,11=2011$, and Ar is the mean allelic richness. 


\section{DISCUSSION}

Monitoring the landscape for $P$. ramorum is an essential part of the management of SOD, and water monitoring is the keystone of early detection in high-risk areas. Although surveys monitor for the presence or absence of $P$. ramorum at any given time or place, they do not provide information about the nature of the pathogen population resident in the water, its genetic diversity and structuring, or the potential for its dispersal and specialization to water. Here, we assess the efficacy of detection techniques and examine the genetic diversity of the waterborne $P$. ramorum population in relation to spatiotemporal and environmental factors. Additionally, by using a population genetics approach, we provide insights into the epidemiology of water-borne $P$. ramorum populations, how they change through time and space, the longevity of inoculum, the potential for transport through waterways, and, finally, the possible sources of water inoculum.

Optimal method and time frame for detection and quantification of $\boldsymbol{P}$. ramorum in the water. The environmental conditions throughout the study period changed significantly between seasons. The study area has a Mediterranean climate, with wetter conditions typically experienced during the winter and early spring months, followed by rising temperatures and a lack of rain throughout the summer months. The intersection of moderate temperature $\left(\approx 14\right.$ to $\left.18^{\circ} \mathrm{C}\right)$ and spring rainfall is known to be conducive to aerial growth and sporulation of $P$. ramorum on its host species $(12,72,79)$. These conditions corresponded with peaks of pathogen recovery from water in both 2009 and 2010, and mirrored other baiting studies $(25,67)$. Water temperatures never exceeded the threshold of $19^{\circ} \mathrm{C}$, a value considered optimal for $P$. ramorum growth (12). Additionally, water temperatures were never colder than $9^{\circ} \mathrm{C}$, a value at which $P$. ramorum can easily survive (90). The necessary presence of rainfall to trigger sporulation has been demonstrated both by methods based on spore counts in rainwater (12) and by measuring sporulation directly on bay leaves (38). However, warmer periods in California are always characterized by an absence of rain; this correlation makes it impossible to statistically separate and quantify the independent effect of each variable on the viability of the pathogen in water. Hence, we opted to use AI, which unifies

TABLE 3. Number of isolates and multilocus genotypes (MLGs) recovered from water sampling in the Pilarcitos and Crystal Springs drainages in 2009 and 2010 , compared with the MLGs identified in soil and leaf samples taken from the same time and location ${ }^{\mathrm{a}}$

\begin{tabular}{|c|c|c|c|c|c|}
\hline \multirow[b]{2}{*}{ Year, drainage } & \multicolumn{2}{|c|}{ All samples } & \multicolumn{3}{|c|}{ Water-only MLGs } \\
\hline & $N$ & MLGs & $N(\%)$ & Total & Singletons (\% of water-only MLGs) \\
\hline \multicolumn{6}{|l|}{2009} \\
\hline Pilarcitos & 86 & 30 & $43(50)$ & $18(60)$ & $13(72)$ \\
\hline \multicolumn{6}{|l|}{2010} \\
\hline Pilarcitos & 141 & 51 & $38(27)$ & $26(84)$ & $20(77)$ \\
\hline Crystal Springs & 52 & 15 & $8(15)$ & $5(16)$ & $3(60)$ \\
\hline
\end{tabular}

a All samples = all isolates recovered from baiting surveys; Water-only MLGs = MLGs that were unique to the water samples when compared with soil and leaf samplings taken from the same drainage and same year; and $N=$ number of isolates, with what percentage of the whole water sample that represents.

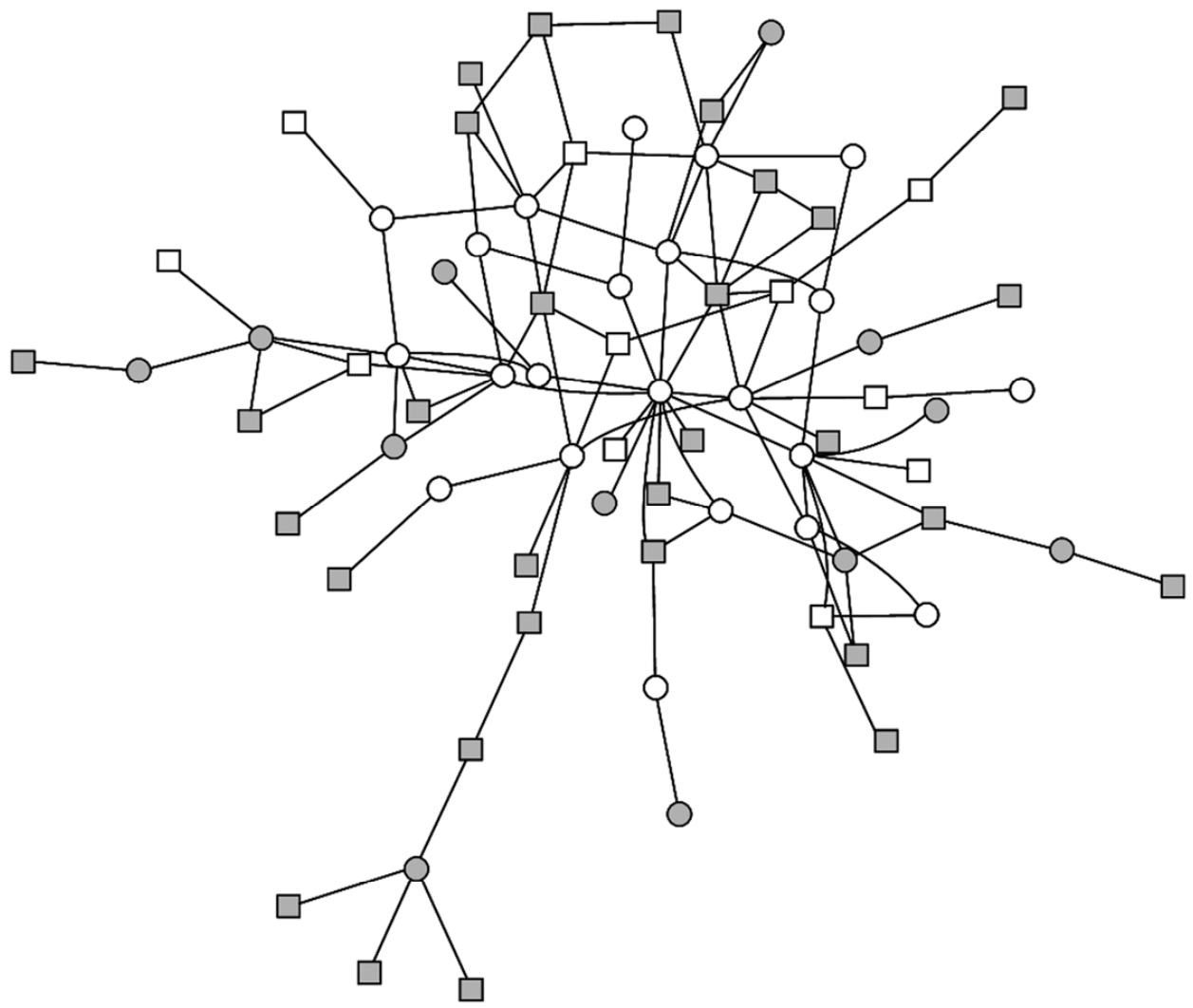

Fig. 5. Minimum spanning network of all multilocus genotypes (MLGs) detected in the water populations in 2009 and 2010. Shaded nodes are genotypes that were only found in the water. Colorless nodes represent MLGs that were also found in soil or leaf populations in the same sampling area and time frame. Square nodes are singleton MLGs. 
the two, as an independent variable. Our data show that in cooler and rainier periods (high AI), viability of the pathogen is higher. The significant correlation between FOI and culture positives indicates that a correlation with preceding inoculum level exists. Additionally, when air temperatures exceed $18^{\circ} \mathrm{C}$, all isolations failed. Based on the results of our multivariate GLM, AI and FOI together are better predictors of positive isolations than either of them separately. We conclude that, after long dry periods, when FOI is extremely low, rainfall is the major driver of viability; as FOI increases, both variables seem to drive an increase in viability but, as temperature continues to rise, it appears to have a negative effect. This has important implications for California, because it suggests that conditions for viability even a few kilometers from true coastal areas may be less frequently optimal, due to the frequent records of average temperatures exceeding $18^{\circ} \mathrm{C}$ in those areas. Finally, the fact that rainfall is required for isolations from water strongly suggests that the source of the water inoculum is mostly aerial, as confirmed by several lines of evidence based on genetic analyses and presented below.

During peak infection times (March to June), both PCR and culturing were highly effective at detecting the presence of $P$. ramorum on symptomatic bait leaves. Culturing was possible during the rainy season when both water and air temperatures were between 10 and $18^{\circ} \mathrm{C}$ while PCR detection was possible independent of recent rainfall and when temperatures ranged between 9 and $18^{\circ} \mathrm{C}$. The comparable temperature values allowing for successful diagnosis by culturing and by PCR point to rainfall as the major driver of isolation success in waterways in the area studied. The vast majority of isolations (Cult+) were also confirmed by PCR (Cult+/PCR+); however, the PCR diagnostic assay extended the period in which $P$. ramorum could be detected into the late summer to fall to winter, when pathogen recovery by culturing failed (Cult-/PCR+). PCR detection when culturing fails may target a $P$. ramorum lesion that is no longer viable, due to less than optimal ecological conditions. If this were the case, baiting may then be the result of a biotrophic process, where lesions are produced on susceptible bait leaves following active infection by a viable pathogen. Alternatively, baiting may be a more passive process: biofilms may form sticky nets on leaves' surfaces, which mechanically catch waterborne dead or dormant inocula, or even pathogen debris (4). In the latter case, pathogen detection would be possible using PCR, despite failure to culture. This second interpretation appears less likely, because it would require trapping of a significant number of propagules, given the limitation of PCR pathogen detection from environmental samples (36).

A few false negatives occurred in our study where culturing allowed for the recovery the pathogen but the PCR diagnostic was negative (Cult+/PCR-). These PCR failures are most likely due to inhibitory compounds in individual samples rather than absence of the pathogen. This rare pattern has been reported in comparative analyses of the efficacy of different diagnostic methods $(49,78)$. The potential, albeit small, for false negatives in any one assay highlights the advantages of using multiple detection methods, especially in critical monitoring areas. We conclude that PCR is the most consistent method for $P$. ramorum detection from bait leaves throughout the year, if only presence or absence is required, but it is most reliable when used in conjunction with culturing. If viable cultures are required for downstream analysis, then baiting should be conducted in the spring months.

Genetic diversity of waterborne $P$. ramorum populations. Overall, population diversity was high but fluctuated seasonally, with similar patterns observed each year. Stoddart and Taylor's $G$ was greatest during the months when pathogen recovery also peaked (May 2009 and March 2010), coinciding with optimal environmental conditions for $P$. ramorum growth and sporulation (12). Favorable conditions promote population growth and an accompanying increase in diversity; in particular, for a species whose genetic diversity has been shown to be generated asexually, presumably by mutations or somatic recombination events (50, 51). Hence, the larger the population, the higher the numbers of possible mutation-induced new MLGs. However, peaks in $G$ coincided with a reduction in evenness, indicating that, although populations are increasing in size and are more diverse overall, they are dominated by a few highly abundant MLGs in these favorable periods. During optimal growth conditions, the pathogen is abundant on leaves, creating higher diversity, but the increased competition for space and resources selects for the dominance of a few highly competitive genotypes (20), decreasing the overall genetic difference among sites: this is a pattern expected for infectious diseases during an epidemic outbreak (20). The intensive 100-leaf sampling showed convincingly that local water populations follow this overall pattern (i.e., a diverse population is dominated by a few highly abundant MLGs when conditions are conducive to the spread of the infectious agent). In other words, it is the combination of diversity and evenness indices that provides the clearest picture of the population dynamics of an infectious agent, with increased diversity combined with reduced evenness being the best indicator of an outbreak. When conditions are less favorable, pathogen recovery decreases and the frequency of each genotype becomes more even, resulting in increased local differentiation and decreased sharing of genotypes across sites: both of these are epidemiological trademarks of a transition to chronic infection levels (20). The transition from chronic to epidemic stage was more pronounced in 2010 than in 2009 , most likely due to the wetter conditions experienced in 2010 after a transition from several drought years prior.

Dispersal of individuals within the watercourses. In a watercourse, wholesale mixing of genotypes is expected due to continuous addition of inoculum from terrestrial sources and downstream movement of inoculum by the current. This is in contrast to what has been reported for soil and leaf populations, both characterized by limited movement of genotypes $(17,51)$. Indeed, spatial autocorrelation analyses found no significant aggregation of similar alleles at any given distance, providing further support for this hypothesis. However, AMOVA revealed a slight structure between upper and lower regions within drainage, with diversity being greater in the lower drainages, especially in the wetter 2010 and 2011. Structure between upper and lower drainages and increased diversity in the lower drainage are two results both in agreement with a process of genotype accumulation occurring downstream. When conditions are less favorable and inoculum loads are low (e.g., in 2009), this accumulation may not be easily detected because individuals may lose viability as they move downstream. However, when inoculum loads are greater, this accumulation effect is likely to be more significant and more easily detectable. Our results match the expectations: genotype accumulation was more easily observed in the more mesic Pilarcitos than in the drier Crystal Springs drainage. The Crystal Springs sites were also spaced further apart, due to more limited access to the watercourse, and this is likely to have a dilution effect, making accumulation less visible. Additionally, in the drier Crystal Springs drainage, this accumulation was only observed when inoculum loads were large in the wetter 2010 and 2011 whereas, in the dry 2009, airborne inoculum being lower resulted in a nonsignificant downstream accumulation of genotypes.

Selection for particular genotypes in the water, and population dynamics of aquatic populations. The dynamics of the water populations in terms of size and genetic diversity closely resemble those observed in soil and leaf populations sampled in the same area and time frame (17). However, the water population was consistently more diverse and more even than that of soil and leaves, and the proportion of singleton MLGs was greatest in water. Singleton MLGs were mostly located around the periphery of the minimum spanning network, and rarely were they retrieved in multiple years. Thus, these singleton MLGs appear to be transi- 
ent evolutionary offshoots that only rarely manage to establish and persist in populations and, therefore, have little influence on population structure. This interpretation was also corroborated by the results of AMOVA analyses, indicating that water populations surveyed in different years were genetically distinct.

The similar patterns in population sizes and diversity observed through time in leaves, soil, and water suggest they are all part of the same epidemiological cycle, likely to be dominated by leaves, currently known as the only major source of inoculum $(12,17)$. $P$. ramorum transmission between hosts occurs mostly via rain splash (12) when environmental conditions are optimal for sporulation, resulting in the accumulation of inoculum in the water, either directly from foliar drops or indirectly from soil runoff. Indeed, as foliar populations decrease in size, so does the successful recovery of cultures from the water, despite the water temperatures remaining optimal. The genetic structure of water populations was less stable than that of foliar or soil populations. In water, there was significant structure between years, and only a low percentage of MLGs survived between years. These findings highlight that water populations are not epidemiologically as relevant as foliar ones. Thus, it appears that the epidemiological trajectory of the water population is inextricably linked to that of leaf and soil populations.

Although the water population is undoubtedly fed by terrestrial sources of inoculum, the large proportion of water-only MLGs could be interpreted as evidence of adaptation to water. $P$. ramorum propagules are able to survive throughout the year in natural waterways $(62,69,70)$, which might support this interpretation. However, the number of water-only MLGs observed to carry over between years was small, indicating that there is little persistence or reproduction of the population in the water. Furthermore, with the exception of a terminal chain of water-only MLGs, there was no significant aggregation of water-only MLGs in the minimum spanning network, indicating lack of specialization of MLGs to the water. Rather, the result of genotypes exclusively retrieved from water may be better explained by the fact that the water environment is less ecologically constraining (i.e., characterized by fewer selective pressures) than the foliar and soil environments, leading to constant differences between spatially and temporally discrete populations. Indeed, AMOVA analysis revealed some structuring between substrates, despite similar rankings of the most abundant MLGs in all three substrates. Singleton MLGs were also more common in the water than in the other substrates which, again, may be attributed to a reduced selection pressure in water, allowing for survival of rarer genotypes. When AMOVA was used to compare whole populations from different substrates, soil and water appear to be more closely related, as would be expected if selection pressure levels were comparable between the two and the source for both was represented by a third population (e.g., leaves). That leaves may represent the main inoculum source for both water and soil is also supported by the fact that the population from leaves is closer to both soil and water, when comparing the most representative genotypes.

Our findings have parallels with the vegetable crop pathogen $P$. capsici which, like $P$. ramorum, has a broad host range and spore dispersal via rain, wind (28), or irrigation water (89). Although found mostly in commercial nurseries and agricultural settings, where it has been regularly isolated from irrigation water $(24,63$, 64,89), $P$. capsici has population characteristics similar to $P$. ramorum: water populations are genetically diverse (26) and may vary depending on the year of sampling $(63,64)$ or location $(89)$. Furthermore, infestations by $P$. capsici have been observed to follow irrigation rows (69). Although water has not yet been shown to be a significant route of infection for $P$. ramorum, its similarity to $P$. capsici, which readily utilizes the water for transmission, together with the ability of $P$. ramorum to travel long distances via watercourses, highlights that the water population has the potential to play a significant role in the pathogen's epi- demiology in natural forest ecosystems. This study is a first foray into studying population genetics of water populations of $P$. ramorum and, at the same time, the study is an intensive survey to test the effectiveness and ability to make predictions of monitoring techniques. Temporally replicated sampling across many sites has provided insight into the epidemiology of the pathogen, and results revealed that the size, diversity, and structure of the water population varies greatly depending on time of year and location, in a pattern closely resembling that of terrestrial populations (17). Baiting has many benefits for monitoring purposes: it is relatively cheap, easy, and reliable, and effectively allows a large area to be surveyed because runoff from a large area will flow over leaves for several weeks. There is a clear window of time when the intersection of rainfall and water temperature is optimal for baiting and culturing. When combined with PCR diagnostics, it was effective for monitoring $P$. ramorum populations resident in the water throughout the year. Predictive models are extremely useful for identifying at-risk areas (54) that should be monitored, and knowledge of the effectiveness of monitoring methods at different times of year will ensure that a suitable method is used. Detection of $P$. ramorum throughout the year confirms that waterways are a significant route of transport for inoculum, even outside of peak times for in planta sporulation. However, viability of water populations surprisingly closely matched viability of aerial populations. This matching pattern of viability may indicate that (i) either the isolation of $P$. ramorum from water is highly dependent on water inoculation from aerial sources or (ii) the viability of the pathogen in California follows a biological clock, with induced dormancy in the summer and most of the autumn. The reported isolation of $P$. ramorum from streams in the states of Oregon and Washington during the summer and fall $(66,76)$, where rainfall is constant throughout the year, suggest that the first hypothesis may be a better explanation for the pattern observed in California. It is still not known whether water-borne inoculum plays a significant role in the spread of SOD in natural ecosystems, although transmission via irrigation water has been shown to be particularly important in commercial nurseries $(39,80)$. It may be that some genotypes have greater capacity for survival in water and travel furthest, giving them some kind of specialization to an exploratory role. Additionally, a correlation has been recently reported between disease incidence and waterways (60), although it is not clear whether the correlation may be due to the presence of favorable ecological factors along waterways or to an active infectious role played by water genotypes. Further research is needed to address this issue. We hope this work will provide a greater understanding of the significant but often cryptic water-borne populations of P. ramorum, and inform strategies for methods and timing for pathogen detection and management.

\section{ACKNOWLEDGMENTS}

We thank the San Francisco Public Utilities Commission for funding; Coastside County water district for site access; field and lab assistants, especially M. Liu. Support was provided by the United States Department of Agriculture Pacific Southwest research station, NSF EID award number 1115607 and the Gordon and Betty Moore Foundation.

\section{LITERATURE CITED}

1. Alexander, J. 2012. The past, present, and future of sudden oak death. Outlooks Pest Manage. 23:72-76.

2. Alexander, J., and Lee, C. A. 2010. Lessons learned from a decade of sudden oak death in California: Evaluating local management. Environ. Manage. 46:315-328.

3. Anacker, B. L., Rank, N. E., Hüberli, D., Garbelotto, M., Gordon, S., Harnik, T., Whitkus, R., Meentemeyer, R. 2008. Susceptibility to Phytophthora ramorum in a key infectious host: Landscape variation in host genotype, host phenotype, and environmental factors. New Phytol. 177:756-766. 
4. Aram, K., and Rizzo, D. M. 2012. New insights into the ecology of Phytophthora ramorum in streams. In: Fifth Sudden Oak Death Sci. Symp. Petaluma, CA.

5. Baldauf, S. 2003. The deep roots of eukaryotes. Science 300:1703-1706.

6. Brasier, C., and Webber, J. 2010. Sudden larch death. Nature 466:824825.

7. Bruvo, R., Michiels, N., D’Souza, T., and Schulenburg, H. 2004. A simple method for the calculation of microsatellite genotype distances irrespective of ploidy level. Mol. Ecol. 13:2101-2106.

8. Chadfield, V., and Pautasso, M. 2012. Phytophthora ramorum in England and Wales: Which environmental variables predict county disease incidence? For. Pathol. 42:150-159.

9. Chastagner, G., Coats, K., Omdal, D., Ramsey-Kroll, A., and Elliott, M. 2011. Mystery on the Sammamish: What are the sources of Phytophthora ramorum infesting this Washington State waterway? (Abstr.) Phytopathology 101:S32.

10. Cobb, R. C., Filipe, J. A. N., Meentemeyer, R. K., Gilligan, C. A., and Rizzo, D. M. 2012. Ecosystem transformation by emerging infectious disease: Loss of large tanoak from California forests. J. Ecol. 100:712722.

11. Croucher, P. J. P., Mascheretti, S., and Garbelotto, M. 2012. Combining field epidemiological information and genetic data to comprehensively reconstruct the invasion history and the microevolution of the sudden oak death agent Phytophthora ramorum (Stramenopila: Oomycetes), in California. Biol. Invas. 10:2281-2297. doi:10.1007/s10530-013-0453-8

12. Davidson, J. M., Wickland, A. C., Patterson, H. A., Falk, K. R., and Rizzo, D. M. 2005. Transmission of Phytophthora ramorum in mixedevergreen forest in California. Phytopathology 95:587-596.

13. De Martonne, E. 1926. L'indice d'aridite. Bull. Assoc. Geogr. Francais 9:3-5.

14. Erwin D. C., and Ribeiro, O. K. 1996. Phytophthora Diseases Worldwide. American Phytopathological Society Press, St. Paul, MN

15. Excoffier, L., and Lischer, H. E. L. 2010. Arlequin suite ver. 3.5: A new series of programs to perform population genetics analyses under Linux and Windows. Mol. Ecol. Resour. 10:564-567.

16. Excoffier, L., and Smouse, P. 1994. Using allele frequencies and geographic subdivision to reconstruct gene trees within a species-Molecular variance parsimony. Genetics 136:343-359.

17. Eyre, C. A., Kozanitas, M., and Garbelotto, M. 2013. Population dynamics of aerial and terrestrial populations of Phytophthora ramorum in a California forest under different climatic conditions. Phytopathology 103:1141-1152.

18. Fichtner, E. J., Lynch, S. C., and Rizzo, D. M. 2007. Detection, distribution, sporulation, and survival of Phytophthora ramorum in a California redwood-tanoak forest soil. Phytopathology 97:1366-1375

19. Filipe, J. A. N., Cobb, R. C., Meentemeyer, R. K., Lee, C. A., Valachovic, Y. S., Cook, A. R., Rizzo, D. M., and Gilligan, C. A. 2012. Landscape epidemiology and control of pathogens with cryptic and long-distance dispersal: Sudden oak death in northern Californian forests. PLoS Comput. Biol. 8:e1002328. doi:10.1371/journal.pcbi.1002328

20. Frank, S. 1992. Models of plant pathogen coevolution. Trends Genet. 8:213-219.

21. Frankel, S. J. 2008. Sudden oak death and Phytophthora ramorum in the USA: A management challenge. Australas. Plant Pathol. 37:19-25.

22. Frankel, S. J., and Hansen, E. M. 2011. Forest Phytophthora diseases in the Americas: 2007-2010. N. Z. J. For. Sci. 41:S159-S167.

23. Garbelotto, M., and Hayden, K. J. 2012. Sudden Oak Death: Interactions of the exotic oomycete Phytophthora ramorum with naïve North American hosts. Eukaryot. Cell 11:1313-1323.

24. Gevens, J., Donahoo, R. S., Lamour, K. H., and Hausbeck, M. K. 2007. Characterization of Phytophthora capsici from Michigan surface irrigation water. Phytopathology 97:421-428.

25. Ghimire, S. R., Richardson, P. A., Kong, P., Hu, J., Lea-Cox, J. D., Ross, D. S., Moorman, G. W., and Hong, C. 2011. Distribution and Diversity of Phytophthora species in nursery irrigation reservoir adopting water recycling system during winter months. J. Phytopathol. 159:713-719.

26. Gobena, D., McGrath, M. T., and Lamour, K. 2012. Survival and spread of Phytophthora capsici on Long Island, New York. Mycol. Prog. 11:761768.

27. Goss, E. M., Larsen, M., Vercauteren, A., Werres, S., Heungens, K., and Grünwald, N. J. 2011. Phytophthora ramorum in Canada: Evidence for migration within North America and from Europe. Phytopathology 101:166-171

28. Granke, L. L., Windstam, S. T., Hoch, H. C., Smart, C. D., and Hausbeck, M. K. 2009. Dispersal and movement mechanisms of Phytophthora capsici sporangia. Phytopathology 99:1258-1264.

29. Grünwald, N. J., Garbelotto, M., Goss, E. M., Heungens, K., and Prospero, S. 2012. Emergence of the sudden oak death pathogen Phytophthora ramorum. Trends Microbiol. 20:131-138.

30. Grünwald, N. J., Goodwin, S. B., Milgroom, M. G., and Fry, W. E. 2003.
Analysis of genotypic diversity data for populations of microorganisms. Phytopathology 93:738-746.

31. Grünwald, N. J., Goss, E. M., and Press, C. M. 2008. Phytophthora ramorum: A pathogen with a remarkably wide host range causing sudden oak death on oaks and ramorum blight on woody ornamentals. Mol. Plant Pathol. 9:729-740.

32. Hansen, E., Goheen, D., Jules, E., and Ullian, B. 2000. Managing PortOrford-cedar and the introduced pathogen Phytophthora lateralis. Plant Dis. 84:4-10

33. Hansen, E. M. 2008. Alien forest pathogens: Phytophthora species are changing world forests. Boreal Environ. Res. 13:33-41.

34. Hansen, E. M., Parke, J. L., and Sutton, W. 2005. Susceptibility of Oregon forest trees and shrubs to Phytophthora ramorum: A comparison of artificial inoculation and natural infection. Plant Dis. 89:63-70.

35. Hardy, O., and Vekemans, X. 2002. SPAGEDi: A versatile computer program to analyse spatial genetic structure at the individual or population levels. Mol. Ecol. Notes 2:618-620.

36. Hayden, K., Ivors, K., Wilkinson, C., and Garbelotto, M. 2006. TaqMan chemistry for Phytophthora ramorum detection and quantification, with a comparison of diagnostic methods. Phytopathology 96:846-854.

37. Hong, C. X., and Moorman, G. W. 2005. Plant pathogens in irrigation water: Challenges and opportunities. Crit. Rev. Plant Sci. 24:189-208.

38. Hüberli, D., Garbelotto, M., Calver, M., and Garbelotto, M. 2012. Intraspecific variation in host susceptibility and climatic factors mediate epidemics of sudden oak death in western US forests. Plant Pathol. 61:579-592.

39. Hulvey, J., Gobena, D., Finley, L., and Lamour, K. 2010. Co-occurrence and genotypic distribution of Phytophthora species recovered from watersheds and plant nurseries of eastern Tennessee. Mycologia 102:1127-1133

40. Hwang, J. S., Oak, S. W., and Jeffers, S. N. 2009. Monitoring occurrence and distribution of Phytophthora species in forest streams in North Carolina using baiting and filtration methods. Pages 91-95 in: Proc. Fourth Meet. IUFRO Working Party: Gen. Tech. Rep. Pac. Southwest Res. Stn. U. S. Dep. Agric. For. Serv. 2009 No. PSW-GTR-221.

41. Ivors, K., Garbelotto, M., Vries, I. D. E., Ruyter-Spira, C., Hekkert, B. T., Rosenzweig, N., and Bonants, P. 2006. Microsatellite markers identify three lineages of Phytophthora ramorum in US nurseries, yet single lineages in US forest and European nursery populations. Mol. Ecol. 15:1493-1505

42. Jeffers S. 2011. Challenges of repeat nurseries. In: California Oak Mortality Task Force 2011 Online Meeting.

43. Kaminski, K., Ufer, T., Wagner, S., Werres, S., Beltz, H., Luttmann, R., Posner, M., Wessels, H. P., and Brand, T. 2005. Introduction of filtration systems in container nurseries for non-chemical elimination of Phytophthora spp. from irrigation water. In: Sudden Oak Death Science Symposium II. Monterey, CA

44. Kanaskie, A., Hansen, E., Goheen, E. M., Osterbauer, N., McWilliams, M., Laine, J., Thompson, M., Savona, S., Timeus, H., Woosley, B., Sutton, W., Reeser, P., Schultz, R., and Hilburn, D. 2011. Progress of the Phytophthora ramorum eradication programme in south-western Oregon forests, 2001-2009. N. Z. J. For. Sci. 41:S169-S175.

45. Kelly, N. M. 2001. Monitoring sudden oak death in California using highresolution imagery. Pages 799-810 in: Proc. Fifth Symp. Oak Woodlands: Oaks in California's Changing Landscape. San Diego, CA. U. S. Dep. Agric. For. Serv. Pac. Southwest Res. Stn. Albany, CA, 2002. Gen. Tech. Rep. PSW-GTR-184.

46. Kinal, J., Shearer, B. L., and Fairman, R. G. 1993. Dispersal of Phytophthora cinnamomi through lateritic soil by laterally flowing subsurface water. Plant Dis. 77:1085-1090.

47. Mai, J. A., Mark, W., Fischer, L., and Jirka, A. 2006. Aerial and ground surveys for mapping the distribution of Phytophthora ramorum in California. Pages 345-360 in: Proc. Sudden Oak Death Second Sci. Symp.: State of Our Knowledge. Gen. Tech. Rep. PSW-GTR-196. U. S. Dep. Agric. For. Serv. Pac. Southwest Res. Stn. Albany, CA.

48. Maloney, P. E., Kane, S. F., Jensen, C. E., and Rizzo, D. M. 2002. Epidemiology and ecology of Phytophthora ramorum in Redwood/tanoak forest ecosystems of the California coast range. In: Proc. Sudden Oak Death Sci. Symp. U. S. Dep. Agric. For. Serv. and University of California, Berkeley.

49. Martin, F. N., Coffey, M. D., Zeller, K., Hamelin, R. C., Tooley, P., Garbelotto, M., Hughes, K. J. D., Kubisiak, T., Bilodeau, G. J., Levy, L., Blomquist, C., and Berger, P. H. 2009. Evaluation of molecular markers for Phytophthora ramorum: Detection and identification: testing for specificity using a standardized library of isolates. Phytopathology 99:390-403.

50. Mascheretti, S., Croucher, P. J. P., Kozanitas, M., Baker, L., and Garbelotto, M. 2009. Genetic epidemiology of the sudden oak death pathogen Phytophthora ramorum in California. Mol. Ecol. 18:4577-4590.

51. Mascheretti, S., Croucher, P. J. P., Vettraino, A., Prospero, S., and 
Garbelotto, M. 2008. Reconstruction of the sudden oak death epidemic in California through microsatellite analysis of the pathogen Phytophthora ramorum. Mol. Ecol. 17:2755-2768.

52. McPherson, B. A., Mori, S. R., Wood, D. L., Kelly, M., Storer, A. J., Svihra, P., and Standiford, R. B. 2010. Responses of oaks and tanoaks to the sudden oak death pathogen after $8 \mathrm{y}$ of monitoring in two coastal California forests. For. Ecol. Manage. 259:2248-2255.

53. Meentemeyer, R., Lotz, E., Rizzo, D. M., Buja, K., and Mark, W. 2006. Early detection monitoring of Phytophthora ramorum in high-risk forests of California. Pages 361-363 in: Proc. Sudden Oak Death Second Sci. Symp.: State of Our Knowledge. Gen. Tech. Rep. PSW-GTR-196. U. S. Dep. Agric. For. Serv. Pac. Southwest Res. Stn. Albany, CA.

54. Meentemeyer, R. K., Cunniffe, N. J., Cook, A. R., Filipe, J. A. N., Hunter, R. D., Rizzo, D. M., and Gilligan, C. A. 2011. Epidemiological modeling of invasion in heterogeneous landscapes: Spread of sudden oak death in California (1990-2030). Ecosphere 2:art17.

55. Meirmans, P., and Van Tienderen, P. 2004. GENOTYPE and GENODIVE: Two programs for the analysis of genetic diversity of asexual organisms. Mol. Ecol. Resour. 4:792-794.

56. Murphy, S., Rizzo, D., Bienapfl, J., Valachovic, Y., Lee, C., Mark, W., Jirka, A., Smith, T., Owen, D., and Adams, D. 2005. Monitoring Phytophthora ramorum distribution in streams within California watersheds. (Abstr.) Phytopathology 95:S72.

57. Oak, S., Hwang, J., and Jeffers, S. 2011. An in vitro baiting assay for recovery of Phytophthora ramorum from waterways. (Abstr.) Phytopathology 101:S131.

58. O'Brien, P. A., Williams, N., and Hardy, G. E. S. 2009. Detecting Phytophthora. Crit. Rev. Microbiol. 35:169-181.

59. Osmundson, T., Eyre, C., Hayden, K., Dhillon, J., and Garbelotto, M. 2013. Back to basics: An evaluation of $\mathrm{NaOH}$ and alternative rapid DNA extraction protocols for DNA barcoding, genotyping, and disease diagnostics from fungal and oomycete samples. Mol. Ecol. Resour. 13:6674.

60. Peterson, E., Hansen, E., and Kanaskie, A. 2014. Spatial relationship between Phytophthora ramorum and roads or streams in Oregon tanoak forests. For. Ecol. Manage. 312:216-224.

61. Prospero, S., Grünwald, N. J., Winton, L. M., and Hansen, E. M. 2009. Migration patterns of the emerging plant pathogen Phytophthora ramorum on the west coast of the United States of America. Phytopathology 99:739-749.

62. Prospero, S., Hansen, E. M., Grünwald, N. J., and Winton, L. M. 2007. Population dynamics of the sudden oak death pathogen Phytophthora ramorum in Oregon from 2001 to 2004. Mol. Ecol. 16:2958-2973.

63. Quesada-Ocampo, L. M., Granke, L. L., and Hausbeck, M. K. 2011. Temporal genetic structure of Phytophthora capsici populations from a creek used for irrigation in Michigan. Plant Dis. 95:1358-1369.

64. Quesada-Ocampo, L. M., Granke, L. L., Mercier, M. R., Olsen, J., and Hausbeck, M. K. 2011. Investigating the genetic structure of Phytophthora capsici populations. Phytopathology 101:1061-1073.

65. Reeser, P. W., Hansen, E. M., and Sutton, W. 2007. Phytophthora siskiyouensis, a new species from soil, water, myrtlewood (Umbellularia californica) and tanoak (Lithocarpus densiflorus) in southwestern Oregon. Mycologia 99:639-643.

66. Reeser, P. W., Sutton, W., Hansen, E. M., Remigi, P., and Adams, G. C. 2011. Phytophthora species in forest streams in Oregon and Alaska. Mycologia 103:22-35.

67. Ristaino, J., and Gumpertz, M. 2000. New frontiers in the study of dispersal and spatial analysis of epidemics caused by species in the genus Phytophthora. Annu. Rev. Phytopathol. 38:541-576.

68. Rizzo, D., Garbelotto, M., Davidson, J., Slaughter, G., and Koike, S. 2002. Phytophthora ramorum as the cause of extensive mortality of Quercus spp. and Lithocarpus densiflorus in California. Plant Dis. 86:205-214.

69. Sanogo, S., and Bosland, P. W. 2013. Biology and management of Phytophthora capsici in the Southwestern USA. Pages 87-95 in: Phytophthora: A Global Perspective. K. Lamour, ed. CABI Plant Protection series No. 2. CABI, Wallingford, UK

70. Schena, L., Duncan, J. M., and Cooke, D. E. L. 2008. Development and application of a PCR-based 'molecular tool box' for the identification of Phytophthora species damaging forests and natural ecosystems. Plant Pathol. 57:64-75.

71. Seipp, D., Brand, T., Kaminski, K., Wagner, S., and Werres, S. 2008. Can Phytophthora ramorum be spread with contaminated irrigation water? Pages 99-100 in: Proc. Sudden Oak Death Third Sci. Symp. Gen. Tech. Rep. PSW-GTR-214. U. S. Dep. Agric. For. Serv. Pac. Southwest Res. Stn. Albany, CA.
72. Sokal, R., and Oden, N. 1978. Spatial Autocorrelation in Biology. 1. Methodology. Biol. J. Linn. Soc. 10:199-228.

73. Stoddart, J., and Taylor, J. 1988. Genotypic diversity-Estimation and prediction in samples. Genetics 118:705-711.

74. Sturrock, R. N., Frankel, S. J., Brown, A. V., Hennon, P. E., Kliejunas, J. T., Lewis, K. J., Worrall, J. J., and Woods, A. J. 2011. Climate change and forest diseases. Plant Pathol. 60:133-149.

75. Suslow, K. 2006. Phytophthora ramorum-economic impacts and challenges for the nursery industry. Pages 41-44 in: Proc. Sudden Oak Death Second Sci. Symp.: State of Our Knowledge. Gen. Tech. Rep. PSW-GTR-196. U. S. Dep. Agric. For. Serv. Pac. Southwest Res. Stn. Albany, CA.

76. Sutton, W., Hansen, E. M., Reeser, P. W., and Kanaskie, A. 2009. Stream monitoring for detection of Phytophthora ramorum in Oregon tanoak forests. Plant Dis. 93:1182-1186.

77. Szpiech, Z. A., Jakobsson, M., and Rosenberg, N. A. 2008. ADZE: A rarefaction approach for counting alleles private to combinations of populations. Bioinformatics 24:2498-2504.

78. Themann, K., Werres, S., Luttmann, R., and Diener, H. 2002. Observations of Phytophthora spp. in water recirculation systems in commercial hardy ornamental nursery stock. Eur. J. Plant Pathol. 108:337-343.

79. Tjosvold, S. A., Chambers, D. L., Koike, S. T., and Mori, S. R. 2008. Disease on nursery stock as affected by environmental factors and seasonal inoculum levels of Phytophthora ramorum in stream water used for irrigation. Plant Dis. 92:1566-1573.

80. Tkacz, B. M., Oak, S. W., and Smith, W. D. 2006. National detection surveys for sudden oak death. In: Proc. Sixth Annu. For. Inventory Anal. Symp. Denver, CO. U. S. Dep. Agric. For. Serv. Gen. Tech. Rep. WO-70. Washington, DC.

81. Tooley, P. W., Browning, M., Kyde, K. L., and Berner, D. 2009. Effect of temperature and moisture period on infection of Rhododendron 'Cunningham's White' by Phytophthora ramorum. Phytopathology 99:1045-1052.

82. Turner, J., Jennings, P., Humphries, G., Parker, S., McDonough, S., Stonehouse, J., Lockley, D., and Slawson, D. 2008. Natural outbreaks of Phytophthora ramorum in the U.K.-current status and monitoring update. Pages 43-48 in: Proc. Sudden Oak Death Third Sci. Symp. Gen. Tech. Rep. PSW-GTR-214. U. S. Dep. Agric. For. Serv. Pac. Southwest Res. Stn. Albany, CA.

83. United States Department of Agriculture, Animal and Plant Health Inspection Service, Plant Protection and Quarantine. 2013. Phytophthora ramorum Nursery Survey. http://www.aphis.usda.gov/plant_health/ plant_pest_info/pram/downloads/surveyplan/2013-SurveyManual.pdf

84. Valachovic, Y., Lee, C., Marshall, J., and Scanlon, H. 2008. Wildland management of Phytophthora ramorum in Northern California forests. Pages 305-312 in: Proc. Sudden Oak Death Third Sci. Symp. Gen. Tech. Rep. PSW-GTR-214. U. S. Dep. Agric. For. Serv. Pac. Southwest Res. Stn. Albany, CA

85. Valiere, N. 2002. GIMLET: A computer program for analysing genetic individual identification data. Mol. Ecol. Resour. 2:377-379.

86. Van Poucke, K., Franceschini, S., Webber, J. F., Vercauteren, A., Turner, J. A., McCracken, A. R., Heungens, K., and Brasier, C. M. 2012. Discovery of a fourth evolutionary lineage of Phytophthora ramorum: EU2. Fungal Biol. 116:1178-1191.

87. Vercauteren, A., De Dobbelaere, I., Grünwald, N. J., Bonants, P., Van Bockstaele, E., Maes, M., and Heungens, K. 2010. Clonal expansion of the Belgian Phytophthora ramorum populations based on new microsatellite markers. Mol. Ecol. 19:92-107.

88. Vettraino, A. M., Sukno, S., Vannini, A., and Garbelotto, M. 2010. Diagnostic sensitivity and specificity of different methods used by two laboratories for the detection of Phytophthora ramorum on multiple natural hosts. Plant Pathol. 59:289-300.

89. Wang, Z., Langston, D. B., Csinos, A. S., Gitaitis, R. D., Walcott, R. R., and $\mathrm{Ji}$, P. 2009. Development of an improved isolation approach and simple sequence repeat markers to characterize Phytophthora capsici populations in irrigation ponds in southern Georgia. Appl. Environ. Microbiol. 75:5467-5473.

90. Werres, S., Marwitz, R., Veld, W., De Cock, A., Bonants, P., De Weerdt, M., Themann, K., Ilieva, E., and Baayen, R. 2001. Phytophthora ramorum sp. nov., a new pathogen on Rhododendron and Viburnum. Mycol. Res. 105:1155-1165.

91. Werres, S., Wagner, S., Brand, T., Kaminski, K., and Seipp, D. 2007. Survival of Phytophthora ramorum in recirculating irrigation water and subsequent infection of Rhododendron and Viburnum. Plant Dis. 91:10341044. 